\title{
Influence of Flexible Work Schedules on Employee Morale
}

\author{
Teresia K.K. Linge $(\mathrm{PhD})$
}

\begin{abstract}
The general objective of the study was determine the effect of flexible work schedules on employee Morale. The study adopted the descriptive research design. The population under study was 60 employees from the health insurance sector in Nairobi. The study applied the convenient sampling method and so all the 60 employees were sampled. For the fisrt level of data analysis, descriptive statistics like means and standard deviations were used. To determine the strength of the association between the dependent and independent variables, Chi square test was computated. The results were presented using Tables.
\end{abstract}

Keywords: Employee morale, Compressed Work Hours, Job Sharing, Flextime, Telecommuting DOI: $10.7176 / \mathrm{EJBM} / 11-5-08$

\section{Introduction}

Flexible work schedule strategy is defined as the range of techniques which enable employees to conduct their work away from the traditional weekly work schedule or outside the normal work schedule (DeNisi \& Griffin, 2008). Going by the above definition a flexible work schedule is one which allows employees and the employer to make changes on when, where and how personal and organizational needs will be met in manner which benefits both parties. Flexibility enables employees to be able to control when, where and how much time they spend working.

The use of flexible work schedule strategies has a positive impact on the work life balance as well as the overall satisfaction of employees. Organizational benefits such as better employee performance, increased organizational commitment, low employee turnover and absenteeism may all result from having good flexible working environment strategies (Shagvaliyeva and Yazdanifard, 2014). Flexible work schedules affects employee job satisfaction (Khan, et al., 2011). Job satisfaction is associated with employee morale (Gupta, 2004). On this basis, one can argue that factors which affect employee job satisfaction may also therefore affect employee morale. Researches have scarcely addressed the influence of flexible work schedules and employee morale.Following this logic, this study sought to contibute to the body of research by scrutinizing the influence of work schedules on employee morale.

\section{Literature Review}

Employee morale refers to attitudes of individuals which affect their willingness to cooperate. High employee morale is demonstrated by enthusiasm, voluntary conformance with regulations and orders and willingness to collaborate with others to achieve organizational goals (Gupta, 2004). High employee morale has been shown as desirable for good performance and productivity. Scholars allude that a number of employee important attitudes including morale could be affected by flexible work schedules. For instance, Armstrong (2006) states that worklife balance policies can help to tackle low employee morale. Also, Dressler (2015 says that flexible schedules are popular with employees.

Flexible work schedules are important because they facilitate the retention of key employees in organizations. They provide employees flexibility to alter their schedules in response to both work and home demands (Beutell, 2010). Flexible work schedules play a significant role in decreasing stress and work family conflict both of which have a huge impact on the performance of employees. Flexible work schedules could lead to factors akin to high employee morale like low absenteeism, good discipline, and better quality of work. Dessler (2015) proposes there are various types of flexible work strategies which include compressed hours, job sharing, work sharing and homeworking/telecommuting.

The term compressed work hours refers to a shedule where the an employee works their standard number of hours but within a shorter time scale. Compressed workweek schedule allows more unrestricted time, which in turn should enable employees to improve on organizational attendance. Employees enjoying more weekends should be better able to balance work and nonwork demands and can thus more easily respond to work-nonwork conflicts and this could reduce employee stress. Decreased employee stress has been linked to decreased absenteeism (Parker and Kulik, 1995) According to Ronen (1984), compressed workweek schedules may positively affect job attitudes by improving or enabling production. Such shedules may increase responsibility, autonomy and job knowledge as they are associated with more positive attitudes toward the job itself.

Job sharing, allows two or more people to share a single full-time job. Job sharing also means a system where employees split one full time job (Drafke and Kossen, 2002). An organization can have two or more part time employees who perform a job that would normally be done by one full time employee. Job sharing can be in the form of divided duties, equally shared responsibilities or even a combination of both. Organizations have found 
that employees who job share are very grateful of the opportunity offered to them and therefore as a result, they put in effort in their jobs. Job sharing also eradicates problems that are caused by vacations and other absences since the sharers usually end up covering for each other (Crampton et al., 2003).A shared job also enables employees to have the opportunity to divide tasks according to their individual interests or skills based on their individual strengths while also ensuring to improve on their weaknesses (Byars and Rue, 2008).

Flexitime entails a work arrangement where start and finish times are flexible. The times are outside core hours, and any excess or deficit in the time worked is carried over to the next period (Armstrong, 2005). Employess work days are built around the core of midday hours, and employees determine, within limits, what other hours they will work. The flexi work time arrangements may enable employees to start earlier than the normal start time and finish earlier or do the reverse by starting and ending a little late. The arrangement enables employees to put in the required number of hours without having to be tardy.

Homeworking/telecommuting is an arranegemnt enables employees to work at home for some days or work entirely from home. The employee use technology to connect to the work place. This trend is popular with employees (Dessler, 2015). It also enables organizations to save on office space thus reducing costs.

\section{Methodology}

The study adopted the descriptive research design. The population under study was 60 employees the in the health insurance sector in Nairobi. Census sampling was applied in this so the whole population was involved. A structured questionnaire was used to collect data. Means and standard deviations were used in the study to determine relationship between fexible work scedules and employee morale. Chi square test was applied to determine the association between flexible works schedules and employee morale. The results are presented using Tables.

\section{Findings}

\subsection{Employee Morale}

The respondents were required to rate their level of morale on a 4 point $\quad$ scale ranging from 1 (low) through 4 (high). The findings showed that a many ( $48 \%$ ) of respondents rated their morale at high $20 \%$ rated it as somewhat high, those who said it was somewhat low were $25 \%$ and only $7 \%$ said it was low. The results are shown in Table 1 .

Table 1: Employee Morale

\begin{tabular}{|l|l|l|}
\hline Level of Morale & Frequency & Percentage \\
\hline High & 29 & 48 \\
\hline Somewhat high & 12 & 20 \\
\hline Somewhat Low & 15 & 25 \\
\hline Low & 4 & 7 \\
\hline TOTAL & 60 & 100 \\
\hline
\end{tabular}

\subsection{Flexible Work Schedules}

Findings showed that the flexible work schedules were applied as follows; $55 \%$ of the respondents reported that they had flextime arrangement, $22 \%$ telecommuting, $14 \%$ compressed work hours and $9 \%$ job sharing. Table 2 shows the results.

Table 2: Types of Flexible Work Schedules

\begin{tabular}{|l|l|l|}
\hline Type of Flexible Work Schedule & Frequency & Percentage \\
\hline Compressed & 8 & 14 \\
\hline Job sharing & 5 & 9 \\
\hline Flextime & 33 & 55 \\
\hline Telecommuting & 13 & 22 \\
\hline TOTAL & 59 & 100 \\
\hline
\end{tabular}

\subsection{Descriptive Statistics and Chi Square Results of Flexible Work Schedules and Employee Morale}

The respondents were required to give their opinion on whether flexible work schedules increased their morale. The opinions were gauged on a 5 point scale ranging from 1 strongly agree through 5 strongly disagree. Compressed hours had the highest mean of 3.92 with a standard deviation of 1.412 , telecommuting had a mean of 3.88 and a standard deviation of 1.302 , Flextime had mean of 3.45 with a standard deviation of 1.316. All these findings point towards agreement. Job sharing had a mean of 3.01 with a standard deviation of 1.375 . This finding is at neutral showing that some respondents were in agreement but others were in disagreement. The composite mean was at 3.56 with a standard deviation of 1.374. This shows that overall many respondents were in agreement that flexible work schedules improved their morale. Chi square test showed that there was a significant relationship between flexible work schedules and employee morale 
$\chi^{2}=38.518 ;$ d.f. $=4 ; \quad P=0.000(P<0.05)$. All these results are shown in Table 3.

Table 3: Descriptive Statistics and Chi Square Results of Flexible Work Schedules and Employee Morale

\begin{tabular}{|l|r|l|l|l|l|}
\hline Constructs & $\mathrm{N}$ & Minimum & Maximum & Mean & Std. Deviation \\
\hline Compressed work hours improve employee morale & 60 & 1 & 5 & 3.92 & 1.412 \\
\hline Job sharing improves employee morale & & 1 & 5 & 3.01 & 1.375 \\
\hline Flextime has improves employee morale & 60 & 1 & 5 & 3.45 & 1.316 \\
\hline Telecommuting improves employee morale & 60 & 1 & 5 & 3.88 & 1.302 \\
\hline Composite mean & 60 & 1 & 5 & 3.56 & 1.374 \\
\hline$\chi^{2}=38.518 ; d . f .=4 ; \quad P=0.000(P<0.05)$ &
\end{tabular}

\section{Discussion and Conclusions}

Findings showed that flexible work schedules had a significance association with employee morale. From the findings it is reasonable to presume that organizations which implemented flexible work schedules were likely to reap the benefits associated with high employee morale like employee enthusiasm, voluntary conformance with regulations and orders, and willingness to collaborate with others to achieve organizational goals (Gupta, 2004). Likewise, findings showed that the respondents agreed that compressed hours improved employee morale. This is in line with Ronen (1984) who said that compressed work hours may positively affect job attitudes by improving or enabling production. These findings mean that the compressed work week is popular with employees. Employees favour to put in more hours in a few days of the week to complete their weekly work load.This kind of arrangement enables them more flexibilty to address personal time needs.

Telecommuting and flextime improved employee morale. These findings are in concurrence with Dessler (2015) who states that telecommuting is popular with employees. Other findings on job sharing showed mixed feelings about this practice. This means that organizations need to implement this practice with caution since some employees may not percieve it a booster to their morale. This study recommends that organizations which which aim at improving employee morale through flexible work schedules should first determine the popular schedules among their employees and make informed decissions on what is suitable for them. This would lead to organizational success in implementation of the practice of flexible work schedules.

\section{References}

Armstrong, M. (2005). A Handbook of Human Resource Management Practice. Kogan Page.

Byars, L.I., \& Rue, L.W. (2008). Human Resource Management. (9 $9^{\text {th }}$ Ed.). New York, NY: Mc GrawHill.

Crampton, S., Douglas, C., Hodge, J., \& Mishra, J. (2003). Job Sharing: Challenges and Opportunities. Seidman Business Review, 9(1), 20-22.

DeNisi, A., \& Griffin, R. (2008). Human Resource Management. (3 ${ }^{\text {rd }}$ Ed.). Boston, MA: Houghton Mifflin Company.

Dessler, G. (2012). Human Resource Management. (13 ${ }^{\text {th }}$ Ed.). New Delhi: Pearson-Prentice Hall.

Dessler, G. (2015). Human Resource Management. (14 ${ }^{\text {th }}$ Ed.). New Delhi: Pearson-Prentice Hall.

Drafke, M.W., \& Kossen, S. (2002). The Human Side of Organizations. ( $8^{\text {th }}$ Ed.). New Jersey, NJ: Prentice-Hall, Inc.

Gupta, C.B. (2004). Human Resource Management. Sultan Chand \& Sons

Hung, J. (1995). The process of facilitating organizational learning in reflective consultation: A case of small and medium sized enterprises in Taiwan. Commerce and Management Quarterly, 3(4), 359-405.

Khan, R.A., Khan, F. A., Khan, D.M \& Shakeel, M. (2011). Impact of Flexible Scheduling on Employee Performance Regarding Stress and Work -Family Conflict. Far East Journal of Psychology \& Business, 4 (3), 1-13.

Parker, P.A., \& Kulik, J.A. (1995). Burnout, self- and supervisorrelated performance, and absenteeism among nurses. Journal of Behavioral Medicine, 18, 581-599.

Pilbeam, S. \& Corbridge, M. (2006). People Resourcing: Contemporary HRM in Practice. Prentice Hall.

Rohen, S. (1984). Alternative Work Schedules: Selecting, Implementing and Evaluating. Homewood, IL: Dow Johns-Irwin.

Shagvaliyeva, S., \& Yazdanifard, R. (2014). Impact of Flexible Working Hours on Work Life Balance. American Journal of Industrial and Business Management, 4, 20-23. 